\title{
Interspecific effects between overstorey and regeneration in small-scale mixtures of three late-successional species in the Western Carpathians (southern Poland)
}

\author{
J. Paluch ${ }^{1}\left[\right.$ [D $\cdot$ L. Bartkowicz ${ }^{1}$ W. Keith Moser ${ }^{2}$
}

Received: 18 September 2018 / Revised: 4 March 2019 / Accepted: 27 June 2019 / Published online: 10 July 2019

(c) The Author(s) 2019

\begin{abstract}
In mixed-species forests, species composition of the overstorey affects regeneration processes through its influence on seed rain intensity and micro-site characteristics. Based on extensive inventory data (1583 sample plots), this study investigated relationships between the percentages of silver fir (Abies alba Mill.), European beech (Fagus sylvatica L.), and Norway spruce (Picea abies (L.) H. Karst.) in the overstorey and in naturally established regeneration (seedlings of a height below $0.5 \mathrm{~m}$ ). A useful framework for this analysis was the assumption that for a given stand density level expected seedling density increases approximately linearly with the increasing percentage of conspecific trees because of increasing seed supply. The analysis partly disproved this assumption and indicated that the species' proportions in the overstorey and regeneration change in a nonlinear manner. In the beech-fir and beech-spruce mixtures, a strong tendency for beech regeneration to increase its proportion was found in the stands with similar percentages of the species. Fir regeneration positively responded to the presence of beech and spruce in the overstorey; an over-proportional increase in fir percentage was found in stands with more than $60 \%$ of beech and, depending on stand density, in a wide range of mixture variants with spruce. These effects may be viewed as increase-when-rare mechanisms that limit superior competitors and counteract the transformation of mixed-species stands into monocultures of spruce or beech. The analysis indicated that reduced stand density considerably facilitates establishment of spruce regeneration in the mixtures with fir and beech, but decreases the percentage of fir regeneration in the mixtures with beech.
\end{abstract}

Keywords Natural regeneration · Mixed forest - Seedling bank · Competitive exclusion · Distance-dependent mortality · Facilitation

Communicated by Christian Ammer.

Electronic supplementary material The online version of this article (https://doi.org/10.1007/s10342-019-01209-y) contains supplementary material, which is available to authorized users.

J. Paluch

jaroslaw.paluch@urk.edu.pl

L. Bartkowicz

leszek.bartkowicz@urk.edu.pl

W. Keith Moser

Warren.K.Moser@usda.gov

1 Faculty of Forestry, University of Agriculture, Al. 29 Listopada 46, 31-425 Cracow, Poland

2 Rocky Mountain Research Station, Forest Service, United States Department of Agriculture, 2500 S. Pine Knoll Drive, Flagstaff, AZ 86001-6381, USA

\section{Introduction}

The species that build multi-species forest communities are frequently characterized by distinctive adaptations and strategies that increase the probabilities of their populations continuing in the presence of other co-occurring species. Ecologically similar species may avoid competitive exclusion in various ways but most often by niche partitioning and exploiting any environmental heterogeneity (Chesson 2000; Wilson 2011). In the case of late-successional species, which regenerate mostly in small canopy gaps or in the shelter of adult trees, one determinant of site heterogeneity is the density and species composition of the canopy layer (Ujházy et al. 2017). Both of these variables influence light availability, physical and chemical topsoil properties, and water accessibility (Barbier et al. 2008). Consequently, they also influence the biotic environment from soil microorganisms 
to mammalian herbivores (Hartley et al. 1997; Carson and Root 2000). In fact, even single allospecific trees are capable of generating micro-sites that contrast greatly in the properties essential for establishing regeneration (Paluch and Stępniewska 2012). For example, lower foliage densities in mixtures with shade-tolerant or mid-tolerant species change solar energy transmittance with consequences for forest floor vegetation and ground-level microclimate (Aussenac 2000). Several studies have also reported increased organic layer depth and lower topsoil $\mathrm{pH}$ near the stem bases of conifers in mixed stands with broadleaf species (Bens et al. 2006; Paluch and Gruba 2012). Tree species also exert different influences on topsoil moisture depending on interception in crowns, the buffering effect of organic layers (Leuschner 2002), water extraction by tree roots (Schume et al. 2003), and stemflow (Levia and Frost 2003). Moreover, root exudates and hyphal linkages to trees and other plants may condition the abundance of soil fungi (Frankland 1998) and enhance mycorrhiza colonization rates (Cline et al. 2007) or seedling mycorrhiza diversity (Grebenc et al. 2009).

Seed rain density often increases in the neighborhood of overstorey trees (Clark et al. 1999; Sagnard et al. 2007), but survival rates of juvenile individuals frequently decrease, a phenomenon commonly labeled the Janzen-Connell hypothesis or distance-dependent mortality (Janzen1970; Connell 1971; Comita et al. 2014). This reduced viability of seeds and seedlings close to the seed-producing trees may result from frugivory (Pérez-Ramos and Marañón 2008), herbivory (Ammer 1996a), population growth of speciesspecific pests and pathogens causing increased incidence (Packer and Clay 2003; Yamazaki et al. 2009; Szwagrzyk et al. 2015), allelopathic effects (Becker and Drapier 1985; Devaney et al. 2018), or strong intraspecific competition for shared resources (Wilson 2011). A similar effect arises when the presence of adult trees of one species - through their influence on biotic or abiotic site variables or availability of resources-facilitate successful regeneration of the other (Hirsch et al. 2012). As a result, conditions for regeneration establishment may be more favorable and seedling densities may be higher in the surroundings of allospecific than conspecific adult trees.

In Europe's montane regions, European beech (Fagus sylvatica $\mathrm{L}$.), silver fir (Abies alba Mill.), and Norway spruce (Picea abies (L.) H. Karst.) commonly form mixed-species stands with dynamics driven by small- to medium-scale disturbances (Kucbel et al. 2012; Král et al. 2014; Paluch et al. 2015). These species not only differ in certain ecological properties but display distinctive regeneration strategies. Beech masts irregularly, at intervals of 3-10 years (Övergaard et al. 2007). The heavy beechnuts usually are dispersed directly below the parent tree's crown (Sagnard et al. 2007), though often subjected to secondary dispersion by frugivores (Millerón et al. 2013). Among the three species studied, spruce produces seeds most frequently and disperses them at the longest distances (Kohlermann1950), a characteristic that facilitates early colonization of canopy openings (Jonášová and Prach 2004). This strategy is crucial for spruce, which-although moderately shade toleranthas the highest light requirements and height growth rate among the three species (Stancioiu and O'Hara 2006). Fir is an extremely shade-tolerant species and can grow under dense canopies for decades yet maintain full potential to respond to release events (Korpel' and Vinš 1965). Beech, in contrast to the conifers, is a typical gap-filler capable of rapid crown spreading and able to outcompete fir in less shaded environments (Nagel et al. 2010; Janík et al. 2016). Nevertheless, explaining the patterns and mechanisms that drive the coexistence of these three late-successional, sympatric species in mixed forests and identifying the processes involved remains a challenge.

The goal of this study was to explore how the local species composition and density of overstorey stands affect regeneration densities of beech, fir, and spruce at a juvenile seedling stage. A natural starting hypothesis for this analysis was that for a constant stand density, seedling densities increase linearly with seed rain intensity and the percentages of seed-producing trees. Accordingly, under neutral conditions (i.e., without interactions between the species), a constant relationship between seedling densities and the percentage of conspecific overstorey trees was expected, and any deviations from this relation would be interpreted as positive or negative interactions between the mixed species as they facilitate or impede the establishment of regeneration. In addition, it was hypothesized that the response of regeneration densities of beech, fir, and spruce to overstorey density is linked with the shade tolerance of these species. Therefore, increasing overstorey density would be expected to affect the less shade-tolerant spruce more markedly than beech and fir.

\section{Methods}

\section{Study region}

The study was carried out in the lower montane belt of the Western Carpathians (southern Poland), which extends between 450 and $1100 \mathrm{~m}$ asl. Depending on altitude, location, and aspect, the average annual temperature in the region is $4-6{ }^{\circ} \mathrm{C}$ with an annual precipitation of $800-1200 \mathrm{~mm}$, $60 \%$ of which occurs between May and October. In the mountain regions, the mean annual temperature decreases about $0.5{ }^{\circ} \mathrm{C}$ per each 100 -m increase in altitude (Paszyński and Niedźwiedź 1999). In the studied portion of the Western Carpathians, a primary parent rock is flysch, which consists of a sequence of sedimentary shales regularly interbedded 
with sandstones. Depending on altitude, the typical soils developed on this bedrock are Dystric, Hapli-Eutric, Eutric, or Endoeutric Cambisols (Brożek and Zwydak 2010).

Analysis was conducted on inventory data collected between 1993 and 2013 in four national parks (NPs; Babiogórski, Bieszczadzki, Gorczański, and Magurski), which represent the best-preserved forest ecosystems in the Polish part of the Carpathians. Most of the study region is occupied by uneven-aged, mixed-species stands comprised mainly of beech, fir, and spruce. In contrast to a typical species composition with a high percentage of beech, the proportion of spruce usually increases at higher altitudes close to the upper montane belt while that of fir increases at lower altitudes on clay soils with a gley horizon (Matuszkiewicz 2001). Nevertheless, in the past, the species composition could have been modified by human activity, including the selective exploitation of beech for fuel and charcoal and the common practices of pasturing, clear cutting (especially in the western part of the Western Carpathians), and promoting conifers through planting or other silvicultural operations. Occasionally, such practices have resulted in the formation of pure forests. The stands are either all-aged with multimodal or reverse J-shaped diameter distributions or, more frequently, show age variations of 30-40 years and diameter distributions similar to the normal distribution. On most of the land of the four NPs, the forests have had passive protection (i.e., no intervention) for at least three decades. In a small portion of the stands (especially in the Babiogórski and Gorczański NPs with the artificially increased proportion of spruce) active forms of protection are currently applied to foster site-specific tree species, mainly by underplanting and release treatments.

\section{Empirical material}

The analysis was based on inventory data collected on sample plots located in regular lattices (Table 1). The dataset excluded any plots located on waterlogged sites, in extensive windthrow areas, or afforested land, as well as those affected by strong disturbances in the last 10 years (with a loss of stand basal area $>25 \%$ ) or located in young stands (with a mean diameter $<30 \mathrm{~cm}$ ). Site variables (altitude, forest association), tree variables (species, diameter at breast height (dbh) of all live trees with $\mathrm{dbh} \geq 7 \mathrm{~cm}$ ), and regeneration densities were registered on each plot (Table 1). The densities of seedlings $\leq 0.5 \mathrm{~m}$ in height (with no 1-year-old individuals) were determined on circular subplots between 5 and $24 \mathrm{~m}^{2}$ in area. The densities of older regeneration (saplings of a height $>0.5 \mathrm{~m}$ and $\mathrm{dbh}<7 \mathrm{~cm}$ ) were also recorded (Table 1), but in this study were used solely as potential predictors of seedling density. Although the dataset included data from consecutive inventories in the Bieszczadzki and Gorczański NPs, the very weak correlation between seedling densities recorded during successive surveys (Pearson correlation coefficients between 0.07 and 0.21 ) indicates that their use did not significantly violate a random sampling assumption. This weak correlation is attributable to general low seedling densities (with a high proportion of plots without regeneration) and a high mortality rate among the juvenile seedlings.

\section{Data analysis}

For straightforward interpretation, the analysis was carried out separately for: beech regeneration in the stands of beech and fir and of beech and spruce; fir regeneration in the stands of beech and fir and of fir and spruce; and spruce regeneration in the stands of spruce and fir and of spruce and beech (Table 2). For any given mixture variant, the calculations included the sample plots on which both species had the highest percentage in the stand basal area of overstorey trees (within the 400 or $500 \mathrm{~m}^{2}$ plot) with a total proportion above $80 \%$. For each mixture, the altitude of plots was restricted to a range in which no significant altitudinal trend in either species composition, stand density or seedling density occurred. In addition, in the calculations pertaining to regeneration of a given species, only those sample plots were included on which at least one tree of this species was potentially
Table 1 Sampling scheme on the inventory plots used in the study

\begin{tabular}{llllllr}
\hline National Park Sampling grid & $\begin{array}{l}\text { Number of } \\
\text { sample plots }\end{array}$ & Census years & $\begin{array}{l}\text { Live trees } \\
d b h \geq 7 \mathrm{~cm}\end{array}$ & $\begin{array}{l}\text { Saplings } \\
h \geq 50 \mathrm{~cm} \text { and } \\
d b h<7 \mathrm{~cm}\end{array}$ & $\begin{array}{c}\text { Seedlings } \\
h<50 \mathrm{~cm}\end{array}$ \\
\hline Babiogórski & $250 \times 250$ & 246 & 2012 & $500^{\mathrm{a}}$ & $10^{\mathrm{a}}$ & $10^{\mathrm{a}}$ \\
Bieszczadzki & $500 \times 500$ & 714 & $1993 / 2009$ & $400^{\mathrm{a}}$ & $100^{\mathrm{a}}$ & $10^{\mathrm{a}}$ \\
Gorczański & $400 \times 400$ & 240 & $1997 / 2007$ & $500^{\mathrm{a}}$ & $100^{\mathrm{a}}$ & $5^{\mathrm{b}}$ \\
Magurski & $500 \times 500$ & 383 & $2003 / 2013$ & $500^{\mathrm{a}}$ & $120^{\mathrm{a}}$ & $24^{\mathrm{c}}$ \\
\hline
\end{tabular}


Table 2 Sample sizes and basic characteristics of the sample plots ordered by variants of species compositions considered in the analyses

\begin{tabular}{|c|c|c|c|c|}
\hline Mixture variants & $\begin{array}{l}\text { Number of sam- } \\
\text { ple plots }\end{array}$ & $\begin{array}{l}\text { Stand basal area } \\
\text { Mean } \pm \text { SD } \\
(\text { Min-max }) \\
\left(\mathrm{m}^{2} \mathrm{ha}^{-1}\right)\end{array}$ & $\begin{array}{l}\text { Relative stand density } \\
\text { Mean } \pm \text { SD } \\
(\text { Min-max) } \\
(\%)\end{array}$ & 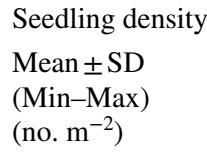 \\
\hline \multicolumn{5}{|c|}{ Overstorey: mixtures of beech and fir (altitude $450-900 \mathrm{~m}$ asl., association $D g-F^{b}$ ) } \\
\hline $\begin{array}{l}\text { Beech regen- } \\
\text { eration }\end{array}$ & 709 & $\begin{array}{l}39.9 \pm 12.6 \\
(14-81)\end{array}$ & $\begin{array}{l}68.8 \pm 21.5 \\
(25-126)\end{array}$ & $\begin{array}{l}1.19 \pm 3.68 \\
(0.00-11.71)\end{array}$ \\
\hline $\begin{array}{l}\text { Fir regenera- } \\
\text { tion }\end{array}$ & 376 & $\begin{array}{l}40.1 \pm 11.0 \\
(17-72)\end{array}$ & $\begin{array}{l}66.7 \pm 25.2 \\
(27-109)\end{array}$ & $\begin{array}{l}0.62 \pm 1.31 \\
(0.00-8.81)\end{array}$ \\
\hline \multicolumn{5}{|c|}{ Overstorey: mixtures of beech and spruce (altitude $700-1100 \mathrm{~m}$ asl., association $D g-F^{b}$ ) } \\
\hline $\begin{array}{l}\text { Beech regen- } \\
\text { eration }\end{array}$ & 497 & $\begin{array}{l}39.5 \pm 12.5 \\
(13-74)\end{array}$ & $\begin{array}{l}70.0 \pm 21.9 \\
(24-128)\end{array}$ & $\begin{array}{l}2.32 \pm 7.13 \\
(0.00-23.21)\end{array}$ \\
\hline $\begin{array}{l}\text { Spruce regen- } \\
\text { eration }\end{array}$ & 225 & $\begin{array}{l}38.2 \pm 12.2 \\
(12-71)\end{array}$ & $\begin{array}{l}67.8 \pm 22.0 \\
(22-128)\end{array}$ & $\begin{array}{l}0.23 \pm 0.65 \\
(0.00-5.64)\end{array}$ \\
\hline \multicolumn{5}{|c|}{ Overstorey: mixtures of fir and spruce (altitude $700-1100 \mathrm{~m}$ asl., associations $D g-F, A-P, G-A^{\mathrm{b}}$ ) } \\
\hline $\begin{array}{l}\text { Fir regenera- } \\
\text { tion }\end{array}$ & 113 & $\begin{array}{l}40.0 \pm 13.1 \\
(11-72)\end{array}$ & $\begin{array}{l}68.7 \pm 23.0 \\
(19-127)\end{array}$ & $\begin{array}{l}0.62 \pm 0.89 \\
(0.00-4.82)\end{array}$ \\
\hline $\begin{array}{l}\text { Spruce regen- } \\
\text { eration }\end{array}$ & 163 & $\begin{array}{l}32.8 \pm 13.4 \\
(9-72)\end{array}$ & $\begin{array}{l}61.2 \pm 23.6 \\
(17-122)\end{array}$ & $\begin{array}{l}0.53 \pm 1.63 \\
(0.00-12.23)\end{array}$ \\
\hline
\end{tabular}

producing seeds. It was assumed that the last condition would be fulfilled for trees of $\mathrm{dbh}>30 \mathrm{~cm}$. Application of this criterion, however, resulted in the data subsets for two species within the same overstorey mixture variant being partly disjointed (e.g., for beech regeneration and fir regeneration in the stands with beech and fir in the overstorey). The sample sizes and basic characteristics of the sample plots ordered by mixture variants are given in Table 2 .

To eliminate the effects of inventory year and location in a given NP (hereafter, location), the seedling densities were standardized separately for location and census year, and then rescaled using a reverse negative binomial distribution with an overall mean and average empirical meanto-variance ratio (Forbes et al. 2011). For each sample plot, calculations were made of relative stand density, and each species' basal area and percentage. For $k$ species represented by $n_{k}$ individuals of each species in a sample plot, the relative stand density (RSD) was determined to be

$\mathrm{RSD}=\sum_{k} n_{k}\left(25 / d b h_{k}\right)^{-a_{k}} / \mathrm{SDI}_{k}$,

where $\mathrm{dbh}_{k}$ is a mean diameter of the $k$ th species and the regionally adapted species-specific parameters $a$ and SDI are 1.629 and 1000 for beech, 1.605 and 1160 for fir, 1.664 and 1000 for spruce, and 1.789 and 650 for other species, respectively. The rationale for using relative stand density is that it allows stand density to be controlled irrespective of a species' percentage in the stand basal area. To account for the effect of stand density on seed production rate per basal area unit, the analyses used three classes of relative stand density: low-density stands (RSD $\leq 60 \%)$, moderate-density dense stands $(60 \%<\mathrm{RSD} \leq 90 \%)$, and high-density stands (RSD > 90\%). Nonetheless, for some density classes, especially high-density stands of the fir-beech, spruce-beech, fir-spruce, or spruce-fir series, the number of the sampled plots was low (between 25 and 42 plots) and the accuracy of the seedling density estimation may be reduced.

The relationships between seedling density and the percentage of conspecific trees, the types of forest association, and the densities of older regeneration (saplings of a height $>0.5 \mathrm{~m}$ and $\mathrm{dbh}<7 \mathrm{~cm}$ ) were examined on scatter plots and if relationships were observed tested by a correlation analysis. Because of skewed distributions, bootstrap procedures were applied to test the significance of the Pearson correlation coefficients (Chernick and LaBudde 2011). Then, a relative seedling density was calculated as a ratio of the empirical seedling densities (per $\mathrm{m}^{2}$ ) and the basal area of the target species in the overstorey stands (in $\mathrm{m}^{2}$ per ha). It was assumed that under neutral conditions (i.e., no interactions between the species) relative seedling density is constant and independent on the percentage of the species at a given overstorey density. Online supplementary material contains results of a simulation study which underpins this assumption and assesses the effect of the different dispersal parameters and seed producer distribution patterns on the seed producer-seed density relation analyzed at small spatial scales. The relationships between the percentage of conspecific trees and relative stand density as predictor variables, and relative seedling density as a response variable, were tested using generalized linear models (GLM) with 
a negative binomial distribution and identity link function. The model parameters were estimated using a maximum likelihood method, and their significance was tested via a Wald statistic and likelihood ratio statistic with goodness of fit expressed by the Nagelkerke pseudo $R$-squared coefficient (Stanisz 2007). The calculations were carried out using STATISTICA, version 9.1. StatSoft, Inc., USA. Finally, the models were used to calculate expected seedling densities in mixed-species stands depending on density and species percentage in the overstorey stand.

\section{Results}

\section{Beech and fir mixtures}

Depending on census year and location, the average densities of beech seedlings ranged between 0.37 and 2.81 individuals per $\mathrm{m}^{2}$, and the overall mean was 1.19 individuals per $\mathrm{m}^{2}$ (Table 2). The densities of beech and fir seedlings, older regeneration (all species), and older beech regeneration were positively correlated $(r=0.19, p=0.01$; $r=0.17, p=0.02 ; r=0.19, p=0.02$, respectively). Beech regeneration density was highest in moderate-density stands $\left(\right.$ mean $\pm \mathrm{SE}=1.34 \pm 0.14$ per $\left.\mathrm{m}^{2}\right)$ and lower in low-density $\left(1.07 \pm 0.12\right.$ per $\left.\mathrm{m}^{2}\right)$ and high-density stands $(0.98 \pm 0.19$ per $\mathrm{m}^{2}$ ). Except for dense stands, the highest relative regeneration density was observable at moderate percentages of beeches in the overstorey (Fig. 1). Although the GLM analysis confirmed this complex effect of beech percentage and the negative effect of stand density on beech seedling density (Table 3), the predictive power of these variables was modest (Nagelkerke pseudo- $R^{2}=0.05$ ).

The average fir seedling density ranged between 0.14 and 0.98 individuals per $\mathrm{m}^{2}$, and the overall mean was 0.62 (Table 2). Fir seedling density was positively correlated with beech seedling density $(r=0.18, p=0.03)$ but showed no significant association with the density of older regeneration (i.e., trees with a height $>0.5 \mathrm{~m}$ and $\mathrm{dbh}<7 \mathrm{~cm}$ irrespective of species; $r=-0.08, p=0.18$ ). The relative density of fir seedlings clearly increased with the decreasing proportion of fir in the basal area but was independent of stand density (Fig. 2). The GLM analysis confirmed the strong positive influence of the decreasing fir percentage in the overstorey on the relative density of fir regeneration (Table 3 ).
Fig. 1 Relative density of beech seedlings in the stands of beech and fir (mean + SE) as a function of stand density and percentage of beech in the stand basal area: a all plots, $n=709$, b density $<60 \%, n=257$, c density $60-90 \%, n=341$, d density $>90 \%, n=111$. The relative seedling density was calculated as a ratio of the empirical seedling densities $\left(\right.$ per $\mathrm{m}^{2}$ ) to the basal area of the species in the overstorey (in $\mathrm{m}^{2}$ per ha). It was assumed that under neutral conditions (i.e., no interactions between the species) and at a given stand density, relative seedling density is constant and independent of the percentage of the species in the overstorey. Any deviations from this relation indicate positive or negative interactions between the mixed species as they facilitate or impede the establishment of regeneration. Line $=$ relative seeding density obtained from the models defined in Table 3 (a) All stands



(c) Moderate-density stands

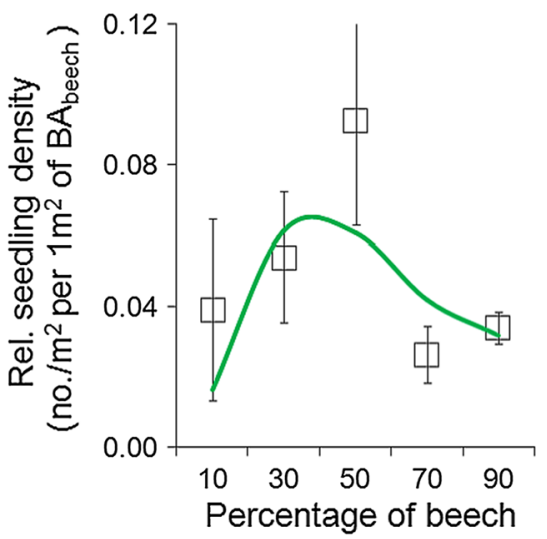

(b) Low-density stands

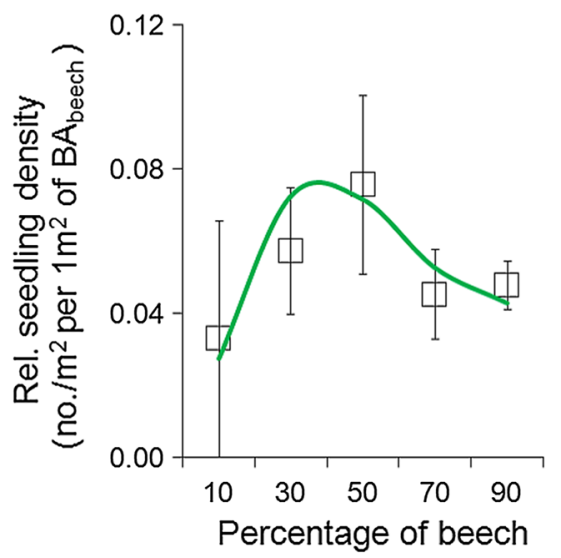

(d) High-density stands

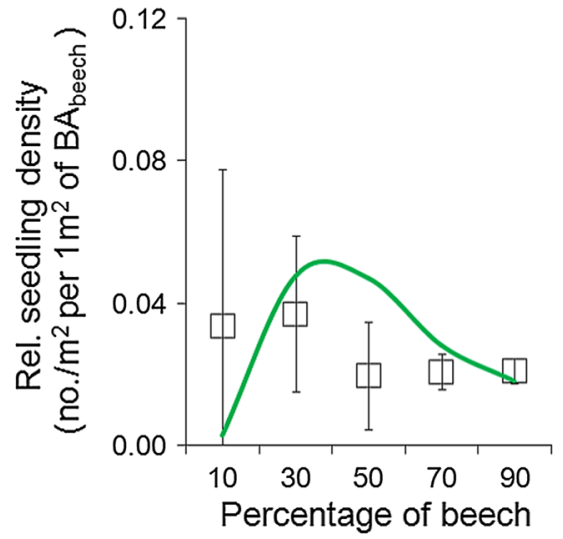


Table 3 Effect of relative stand density and the percentage of conspecific trees on fir, beech, and spruce regeneration in mixed-species stands

\begin{tabular}{|c|c|c|c|c|c|c|c|c|c|}
\hline $\begin{array}{l}\text { Mixture vari- } \\
\text { ants }\end{array}$ & Variables $^{\mathrm{a}}$ & Param. estimate & SE & Wald stat. & $p$ value & $-\operatorname{Ln}(\mathrm{L})$ & Chi-sq. & $p$ value & Nagelkerke $R^{2}$ \\
\hline \multicolumn{10}{|c|}{ Overstorey: mixtures of beech and fir } \\
\hline \multirow{4}{*}{$\begin{array}{l}\text { Beech regen- } \\
\text { eration }\end{array}$} & $\mathrm{BA} \%_{\text {beech }}$ & 58.51 & 9.49 & 38.0 & $<0.001$ & 5830 & - & - & - \\
\hline & $\mathrm{BA} \%_{\text {beech }}^{2}$ & -1.08 & 0.22 & 22.8 & $<0.001$ & 5813 & 32.9 & $<0.001$ & - \\
\hline & $\mathrm{BA} \%_{\text {beech }}^{3}$ & 0.0057 & 0.0014 & 15.8 & $<0.001$ & 5809 & 9.3 & 0.002 & - \\
\hline & RSD & -4.37 & 1.45 & 9.1 & 0.003 & 5805 & 9.0 & 0.003 & 0.05 \\
\hline \multirow{3}{*}{$\begin{array}{l}\text { Fir regenera- } \\
\text { tion }\end{array}$} & Intercept & 1077.70 & 177.98 & 36.7 & $<0.001$ & 2147 & - & - & - \\
\hline & $\mathrm{BA} \%_{\text {fir }}$ & -22.55 & 6.28 & 12.9 & $<0.001$ & 2140 & 14.7 & $<0.001$ & - \\
\hline & $\mathrm{BA} \%_{\text {fir }}^{2}$ & 0.14 & 0.05 & 6.9 & 0.009 & 2137 & 5.6 & 0.018 & 0.08 \\
\hline \multicolumn{10}{|c|}{ Overstorey: mixtures of beech and spruce } \\
\hline \multirow{3}{*}{$\begin{array}{l}\text { Beech regen- } \\
\text { eration }\end{array}$} & BA $\%_{\text {beech }}$ & 114.81 & 16.81 & 46.7 & $<0.001$ & 4420 & - & - & - \\
\hline & $\mathrm{BA} \%_{\text {beech }}^{2}$ & -2.42 & 0.46 & 28.2 & $<0.001$ & 4404 & 32.1 & $<0.001$ & \\
\hline & $\mathrm{BA} \%_{\text {beech }}^{3}$ & 0.013 & 0.003 & 20.2 & $<0.001$ & 4394 & 19.8 & $<0.001$ & 0.06 \\
\hline \multirow{2}{*}{$\begin{array}{l}\text { Spruce regen- } \\
\text { eration }\end{array}$} & Intercept & 928.51 & 268.92 & 11.9 & $<0.001$ & 1892 & - & - & - \\
\hline & RSD & -7.87 & 3.77 & 4.3 & 0.037 & 1887 & 10.2 & $<0.001$ & 0.07 \\
\hline \multicolumn{10}{|c|}{ Overstorey: mixtures of fir and spruce } \\
\hline \multirow{2}{*}{$\begin{array}{l}\text { Fir regenera- } \\
\text { tion }\end{array}$} & Intercept & 835.46 & 225.04 & 13.8 & $<0.001$ & 621 & - & - & - \\
\hline & $\mathrm{BA}_{\text {fir }}$ & -7.24 & 2.53 & 8.1 & 0.004 & 615 & 11.7 & $<0.001$ & 0.11 \\
\hline \multirow{2}{*}{$\begin{array}{l}\text { Spruce regen- } \\
\text { eration }\end{array}$} & Intercept & 627.82 & 227.41 & 37.9 & $<0.001$ & 1258 & - & - & - \\
\hline & RSD & -6.03 & 3.62 & 2.8 & 0.01 & 1251 & 18.0 & $<0.001$ & 0.16 \\
\hline
\end{tabular}

${ }^{a} R S D$ relative stand density (in \%), see "Methods", BA\% species percentage of the species in stand basal area (in \%)

\section{Beech and spruce mixtures}

Depending on census year and location, the beech seedling densities ranged between 0.75 and 3.90 individuals per $\mathrm{m}^{2}$, and the overall mean was 2.32 individuals per $\mathrm{m}^{2}$ (Table 2). Similar to the beech-fir mixtures, the highest relative regeneration density was found at moderate percentages of beeches in the overstorey (Fig. 3). However, unlike the stands with fir, the effect of relative stand density turned out not to be significant (Table 3).

The average spruce seedling densities ranged between 0.08 and 0.47 individuals per $\mathrm{m}^{2}$, and the overall mean was 0.23 individuals per $\mathrm{m}^{2}$ (Table 2). Although spruce seedling density was weakly and positively correlated with beech seedling density $(0.14, p=0.04)$, it was negatively correlated with the density of older regeneration $(r=-0.13$, $p=0.12$ ). Spruce seedling density did increase approximately linearly with an increasing basal area of conspecific mature trees $(r=0.11, p<0.05)$. The relative seedling density (i.e., the ratio of seedling density and basal area of spruces in the overstorey) was constant and independent of the spruce percentage (Fig. 4). However, spruce seedling density significantly decreased in high-density stands, with no spruce seedlings recorded in high-density beech stands with a minor admixture of spruce and a relative density above $90 \%$. The GLM analysis confirmed the strong negative effect of stand density on relative spruce seedling density (Table 3).

\section{Fir and spruce mixtures}

The average fir seedling densities ranged between 0.42 and 0.90 individuals per $\mathrm{m}^{2}$, and the overall mean was 0.62 individuals per $\mathrm{m}^{2}$ (Table 2). The densities of fir seedlings, spruce seedlings, and older regeneration were uncorrelated. The abundance of fir seedlings did not differ significantly in the high-, moderate-, and low-density stands. However, as with mixtures of beech and fir, the plots with a small proportion of fir had the highest relative seedling densities (Fig. 5). The percentage of fir in the overstorey explained approximately $11 \%$ of the total variation in relative density of fir seedlings (Table 3).

The average spruce seedling densities ranged between 0.28 and 0.62 individuals per $\mathrm{m}^{2}$, and the overall mean was 
Fig. 2 Relative density of fir seedlings in the stands of beech and fir (mean + SE) as a function of stand density and percentage of fir in the stand basal area: a all plots, $n=376, \mathbf{b}$ density $<60 \%$, $n=142$, c density $60-90 \%$, $n=192, \mathbf{d}$ density $>90 \%, n=42$. Line $=$ regression line calculated for parameters given in Table 3 . For additional explanation, see Fig. 1 (a) All stands

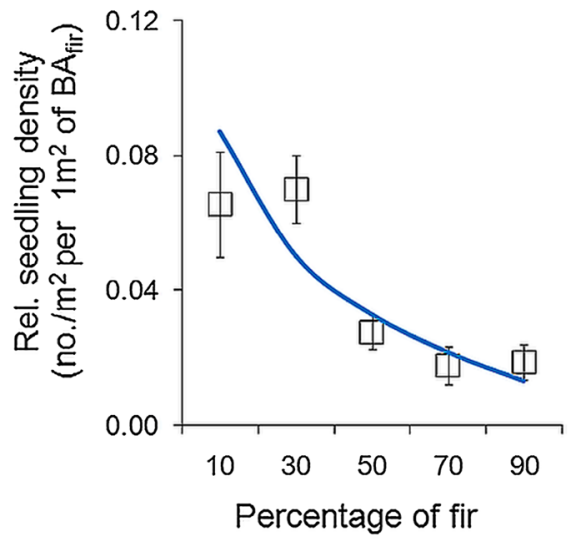

(c) Moderate-density stands

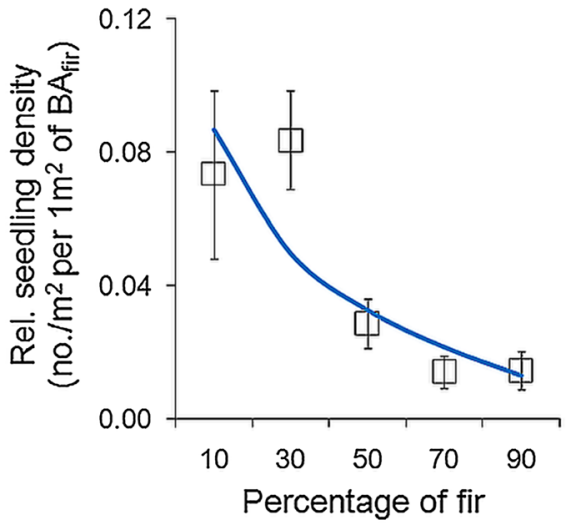

(b) Low-density stands

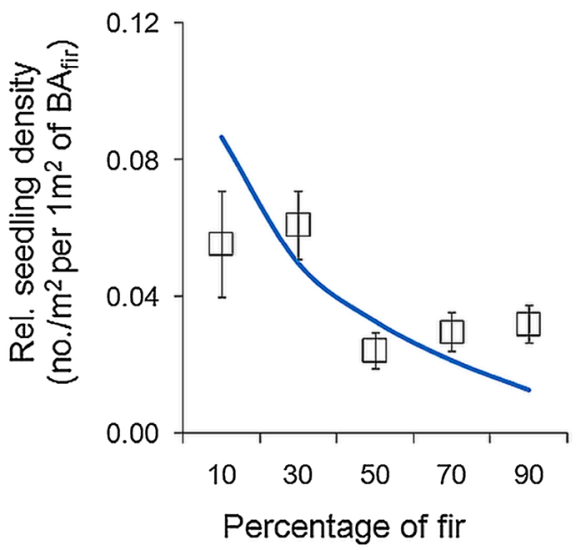

(d) High-density stands

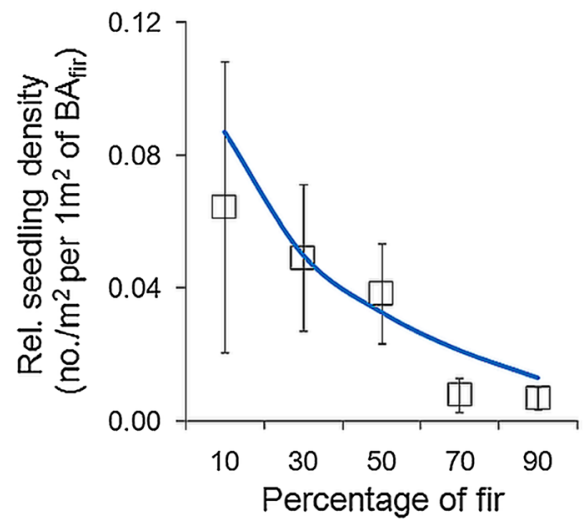

0.53 individuals per $\mathrm{m}^{2}$ (Table 2). Spruce seedlings tended to occur more frequently in low- and moderate-density stands (mean \pm SE was $0.64+0.06$ and $0.49 \pm 0.06$, respectively) than in high-density stands $(0.23 \pm 0.19)$. Overall, the GLM analysis confirmed the negative effect of stand density (Nagelkerke pseudo $R$-squared coefficient 0.16) (Table 3). The effect of percentage of spruce in the overstorey on relative density of conspecific seedlings was not significant (Fig. 6).

\section{Comparing interactions between the species}

Regeneration of beech, fir, and spruce responded differently to the admixed species in the overstorey stands (Fig. 7). In the case of spruce regeneration, no interaction was found in the mixtures containing either beech or fir, thus indicating that spruce seedling densities increased approximately proportionally to the percentage of this species in the overstorey. In the case of fir regeneration (Fig. 7), the ratios attained the highest values in the stands with a large proportion of allospecific trees in mature stands $(>80 \%)$. In these stands, they were approximately four- to ninefold higher in the mixtures with spruce or beech, respectively, than in the pure fir forests. For beech regeneration (Fig. 7), the strongest positive interaction occurred in the range of allospecific tree percentages between 50 and $70 \%$. The relative seedling densities were insignificantly lower in allospecific stands with dominating fir or spruce than in pure beech stands.

In the mixtures with beech, this species considerably outnumbers fir and especially spruce, even in stands with a higher percentage of conifers. Fir seedling densities will be higher than beech seedling densities only in stands with $>75 \%$ of fir (Figs. 8 and 9). A disproportionate increase of the fir percentage in the regeneration layer relative to fir's percentage in stand basal area is expected only in more dense stands with $<40 \%$ of fir, although. Likewise, spruce seedlings are expected to occur at densities comparable to beech in stands with $>70$ and $80 \%$ of mature spruces (for $\mathrm{RSD}=50$ and $80 \%$, respectively). The largest differences between beech and spruce seedling densities occur at higher stand densities and in stands with a balanced percentage of beech and spruce in the overstorey (Figs. 8, 9). In fir-spruce mixtures, regardless of species percentage in the overstorey, the proportion of fir tends to be higher in regeneration than in stand basal area, and the highest fir seedling densities 
Fig. 3 Relative density of beech seedlings in the stands of beech and spruce $($ mean $+\mathrm{SE})$ as a function of stand density and percentage of beech in the stand basal area: a all plots, $n=497$, b density $<60 \%, n=168$, c density $60-90 \%, n=234$, $\mathbf{d}$ density $>90 \%, n=95$. For additional explanation, see Fig. 1


(c) Moderate-density stands



(d) High-density stands

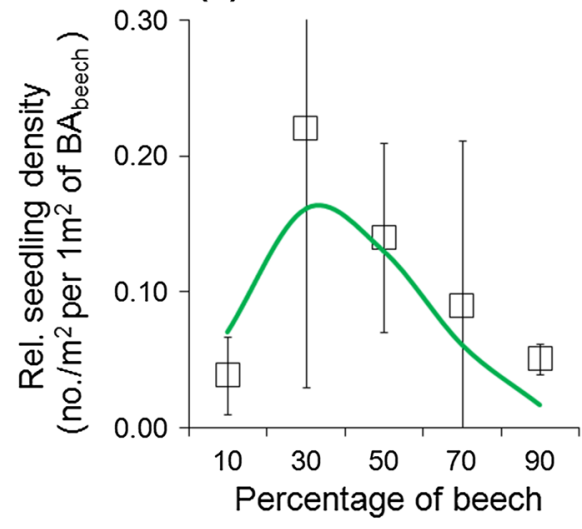

are expected in forests with about $40 \%$ spruce (Figs. 8, 9). Moreover, fir regeneration benefits from increasing stand density. Spruce considerably outnumbers fir only in stands with a high percentage of conspecific trees in the overstorey (>65-85\%, depending on stand density).

\section{Discussion}

Unlike an earlier analysis of stand-level records (Paluch and Jastrzębski 2013), this study uses data from small sample plots which ensure accurate information on local stand density and species composition. Along with seed supply, these variables determine light conditions, topsoil properties, and forest floor features crucial for germination and early survival of seedlings. Using small inventory plots, however, poses a risk that the percentage of mother trees on the sample plots may not reflect empirical seed densities. Though this constraint may be considered of negligible importance in the case of heavy-seeded beech, it is more important for lighter seed weight species like fir and particularly spruce, which are characterized by a lower seed falling velocity ( 0.85 and $1.25 \mathrm{~s} \mathrm{~m}^{-1}$, respectively; Kohlermann 1950) and higher seed dispersal distances. For example, for firs growing in forest interiors median dispersal distances of between 6 and $22 \mathrm{~m}$ were reported by authors using seed trap methodology (Sagnard et al. 2007; Paluch 2011; Amm et al. 2012; De Andrés et al. 2014). Distances covered by spruce seeds are longer by about $35-50 \%$ compared to fir (Kohlermann 1950). Hence, in the case of fir and spruce, this analysis assumes that species composition within and beyond the sample plots does not differ significantly and that possible variations are random. Admittedly, the simulation study (Supplementary material) suggests that in the case of species which disperse their seeds farther the variation in ground seed density should decrease and thus partly offset by the effects of their irregular spatial distribution. Nonetheless, the bias is expected to strongly increase for low densities of mother trees and their higher average fecundity rates. In such situations, the results obtained for a small number of sampled plots, as in high-density stands for fir or spruce regeneration in this study, should be treated with caution (see Supplementary material).

In addition to the small area of the sample plots, in which local species compositions and densities may diverge from the surrounding stands, the modest predictive power of the regeneration density models obtained in this study may be attributed to other factors. Some possible explanatory 
Fig. 4 Relative density of spruce seedlings in the stands of beech and spruce (mean + SE) dependent on stand density and percentage of spruce in the stand basal area: $\mathbf{a}$ all plots, $n=225$, b density $<60 \%, n=85$, c density $60-90 \%, n=100$, d density $>90 \%, n=40$. For additional explanation, see Fig. 1 (a) All stands

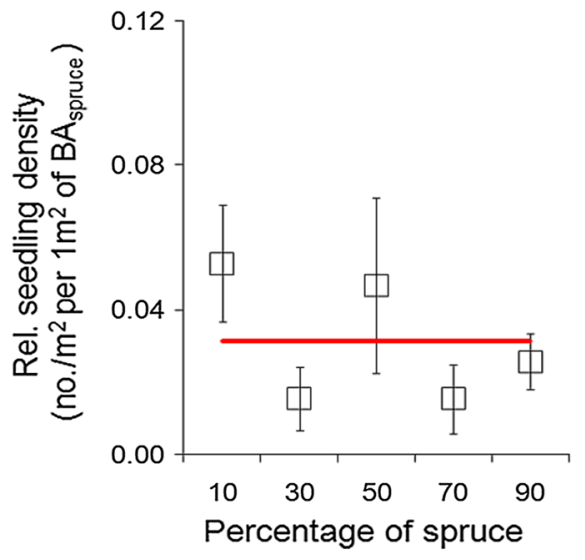

(c) Moderate-density stands

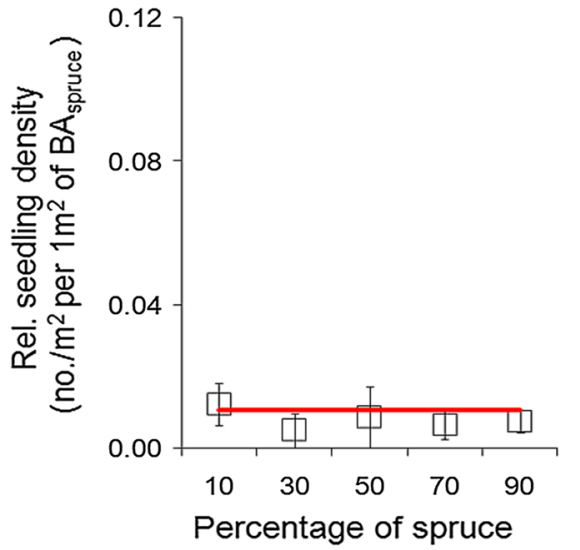

(b) Low-density stands

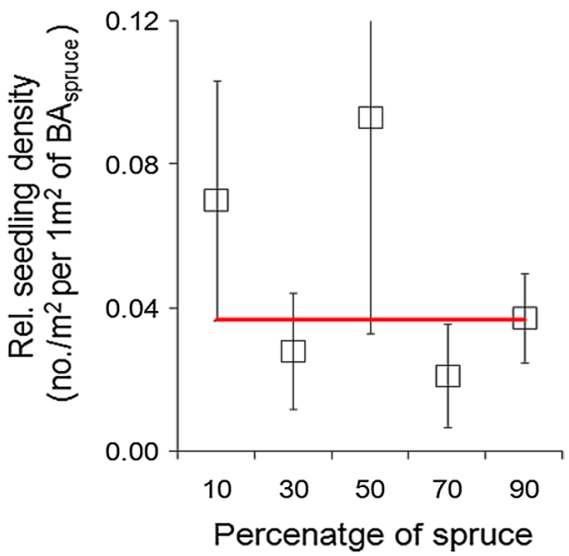

(d) High-density stands



variables are variation in fecundity of the seed trees and quality of their seeds, differences in ungulate herbivore pressure, local micro-topography with its effect on topsoil properties, variation in forest floor vegetation, or presence of woody debris. Moreover, the earlier study (Paluch et al. 2016) indicated that the spatial range of influence of singledispersed overstorey conifer trees on topsoil properties, forest floor vegetation, and regeneration may be restricted to distances not much larger than their crown width. Therefore, the spatial scale considered in the current study (400 or $500 \mathrm{~m}^{2}$ ) may only approximately reflect species-specific effects of single trees attributable to smaller scales.

\section{Beech regeneration}

In beech-fir and beech-spruce mixtures, the relative density of beech regeneration responded negatively to stand density and positively to the increasing percentage of conspecific trees in the stand basal area, particularly in the range between 20 and $60 \%$ (Fig. 9). Given the moderate beech seedling densities registered on the sample plots (maximum of 12 per $\mathrm{m}^{2}$ in the beech-fir mixtures and 23 per $\mathrm{m}^{2}$ in the beech-spruce mixtures), density-dependent mortality may not be a potential explanation. However, beechnuts are highly attractive to seed predators, and the disproportionate increase of regeneration density documented here is consistent with the satiation hypothesis that a higher abundance of resources increases the probability of a seed's escaping from predators and establishing as a seedling (Kelly and Sork 2002; Schnur et al. 2004). Thus, the lower relative seedling densities in stands with a low percentage of beeches $(<20 \%)$ may be explained by a reduced seed supply and effective predation of beech seeds by small mammals in conifer stands with a small admixture of beeches. Nevertheless, the capacity of a rodent population to affect seed reserves depends on current predator abundance, the overall rate of seed consumption, and actual seed production, so the potential influence of this factor is often difficult to predict (Ruscoe et al. 2005). In addition, the lower relative seedling densities in stands with a low percentage of beeches are hypothetically attributable to higher light penetration in beech-conifer mixtures (Juchheim et al. 2017; Fotis et al. 2018), which increases fecundity among the seed producers and also favors the survival and growth of older beech seedlings (Szwagrzyk et al. 2001). 
Fig. 5 Relative density of fir seedlings in the stands of fir and spruce $($ mean $+\mathrm{SE})$ dependent on stand density and percentage of fir in the stand basal area: $\mathbf{a}$ all the plots, $n=116$, b density $<60 \%, n=41$, c density $60-90 \%, n=50$, d density $>90 \%, n=25$. For additional explanation, see Fig. 1 (a) All stands

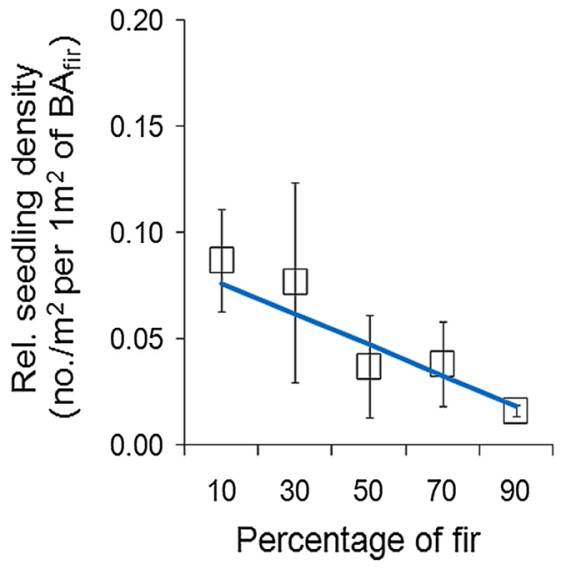

(c) Moderate-density stands

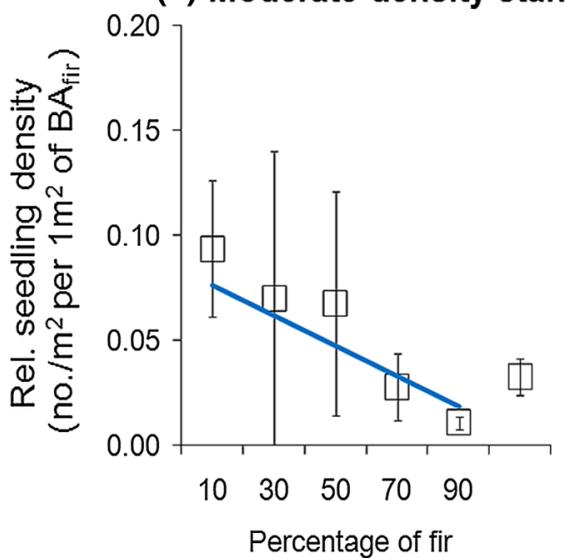

(b) Low-density stands



(d) High-density stands

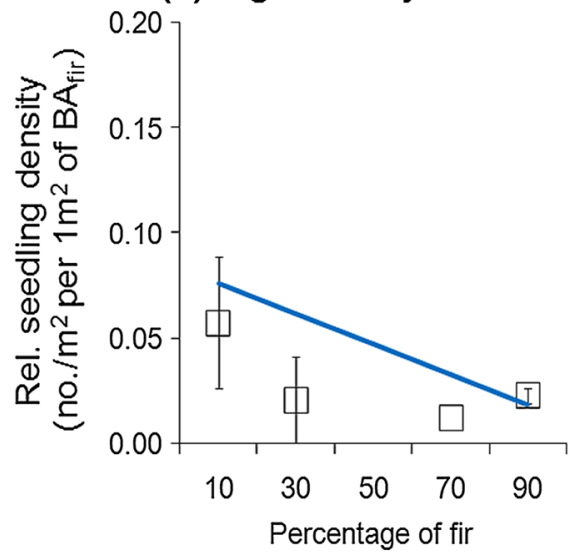

Another factor that can be plausibly linked to facilitation effects in mixtures of beech and conifers are seedbed properties that frequently control the early stages of regeneration establishment (Madsen 1995; Peltier et al. 1997; Wagner et al. 2010). Mixed-species stands may have higher litter decomposition rates than monocultures, indicating a lower likelihood of the accumulation of a thick organic matter layer (Polyakova and Billor 2007). An eventual effect of seedling herbivory seems less probable because in a study region characterized by considerable species and structural landscape diversity, beech seedlings are not among the preferred species.

\section{Fir regeneration}

The relative density of fir regeneration responded positively to the increasing percentage of beech and spruce in mature stands (Fig. 9). Numerous studies have reported the positive influence of allospecific trees on fir regeneration (Schrempf 1978; Šimak 1951; Mayer 1960; Jaworski 1973; Jaworski et al. 1985; Dobrowolska 1998; Dobrowolska and Veblen 2008; Paluch and Jastrzębski 2013; Paluch et al. 2016), and several factors might hypothetically be involved in this facilitation mechanism. For instance, lower foliage density in mixed stands with less shade-tolerant species like spruce, differences in phenological phases of coexisting tree species (fir vs. beech), or different canopy architecture in pure versus mixed stands increase light penetration and light-use efficiency (Robakowski et al. 2004; Forrester and Albrecht 2014; Pretzsch 2014; Forrester and Bauhus 2016) and may result in increasing seed production. Higher light penetration results in higher forest floor temperatures and an earlier snowmelt, which enhances germination and survival rate (Duchesneau and Morin 1999; Simard et al. 2003). Tree species also may exert different influences on topsoil moisture. Under conditions of summer drought, topsoil water content in beech-fir mixtures is likely to be affected more strongly by increasing density of fir than beech, while in spruce-fir mixtures topsoil moisture decreases approximately twice as much around spruces as around firs (Paluch and Gruba 2012). Hence, the availability of soil water for seedlings is better in mixtures with beech and worse in mixtures with spruce than in pure fir forests. Stand species composition also affects ectohumus layer depth, which up to a given level may facilitate establishment of fir seedlings but in excess 
Fig. 6 Relative density of spruce seedlings in the stands of fir and spruce $($ mean $+\mathrm{SE})$ dependent on stand density and percentage of spruce in the stand basal area: a all plots, $n=165$, b density $<60 \%, n=90$, c density $60-90 \%, n=50$, d density $>90 \%, n=25$. For additional explanation, see Fig. 1
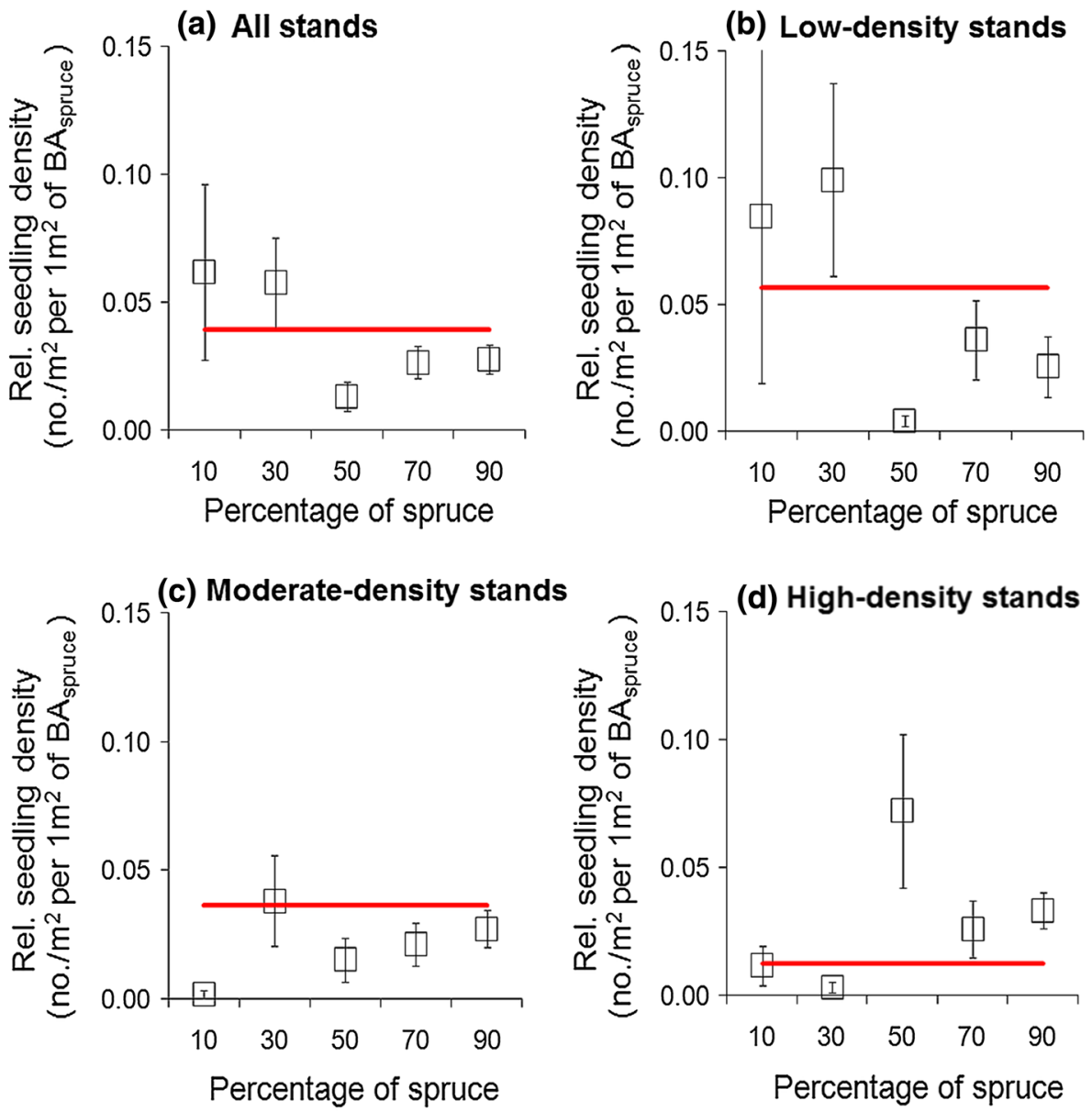

may hinder sprouting and juvenile survival (Korpel' and Vinš 1965; Huth et al. 2017). In addition, some studies have demonstrated that seed burial favors the recruitment of seedlings, preventing desiccation and stimulating germination (Tan and Bruckert 1992; Gómez 2004).

The distance-dependent mortality of fir regeneration can also be attributed to allelopathic effects (Becker and Drapier 1985) or biotic factors. Paluch and Stępniewska (2012) documented a negative effect of fungal pathogens in pure A. alba forests in the Western Carpathians, which resulted in irregular, strongly clumped distribution patterns of regeneration. Jankowiak et al. (2016) determined that the fungi Gyoerffyella rotula and other closely related species that cause fir seedling die-off are strongly associated with fir stands but not with mixed stands with a majority percentage of beech. Other experimental studies have indicated that fir seedlings growing on mineral soil are more prone to fungal attacks than those growing on the ectohumus layer (Paluch and Stępniewska 2012). Thus, a thicker ectohumus layer developing in the vicinity of conifer species stems, particularly spruce (Paluch and Gruba 2012), may reduce the pathogen incidence associated with Gyoerffyella species. In the study region, fir regeneration is subject to enhanced pressure from herbivores (Cervus elaphus L. and Cervus capreolus L.), who show a higher preference for fir than for beech or spruce. Hence, the variation in seedling density between stands of different species composition may be partly attributable to density-dependent herbivory (with greater pressure in stands with a high proportion of $A$. alba because of a higher availability of the preferred species). This selective browsing pressure can be mitigated in stands with mixed-species regeneration (Ohse et al. 2017).

\section{Spruce regeneration}

In the mixtures with beech and fir, the relative density of spruce seedlings was not related to the percentage of spruce in the stand basal area (Fig. 9). In both cases, however, spruce regeneration increased with decreasing stand densities. This trend is in line with long-distance seed dispersal (Grassi et al. 2004) and relatively lower shade tolerance of spruce as compared to fir and beech (Ammer 1996b; Hunziker and Brang 2005). Moreover, one factor that may hinder spruce regeneration establishment in dense stands with a high proportion of beech is a thick litter layer, which is a major driver of understorey plant diversity in beech forests 
Fig. 7 Expected seedling densities as a function of percentage of conspecific trees and relative stand density in stands of beech and fir (top panels), beech and spruce (middle panels), and fir and spruce (bottom panels). RSD relative stand density (in $\%$ ), see "Methods". Calculations were based on the generalized linear models with parameters given in Table 3
Moderate-density stands

(RSD $=80 \%$ )

Percentage of beech

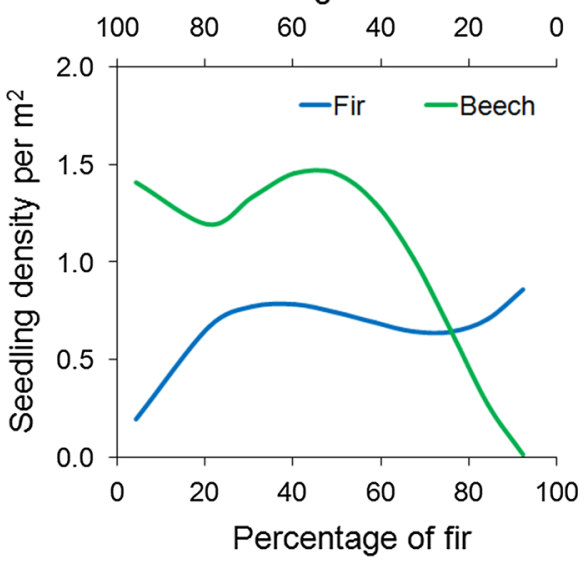

Percentage of beech



Percentage of fir

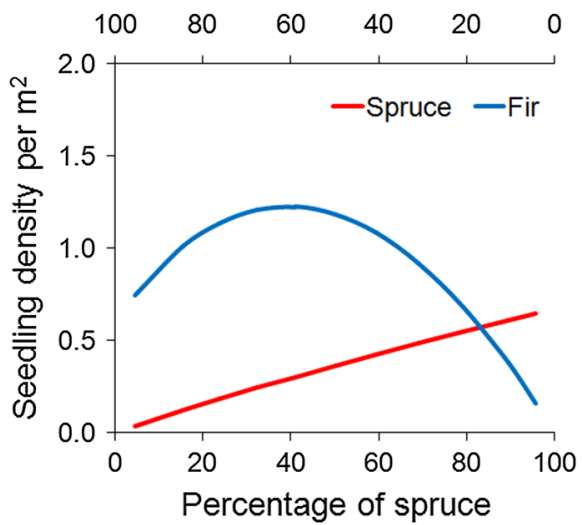

Low-density stands

(RSD $=\mathbf{5 0} \%$ )

Percentage of beech

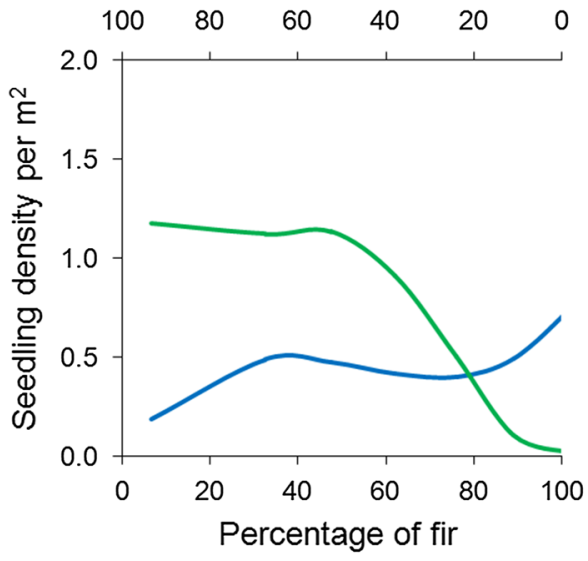

Percentage of beech

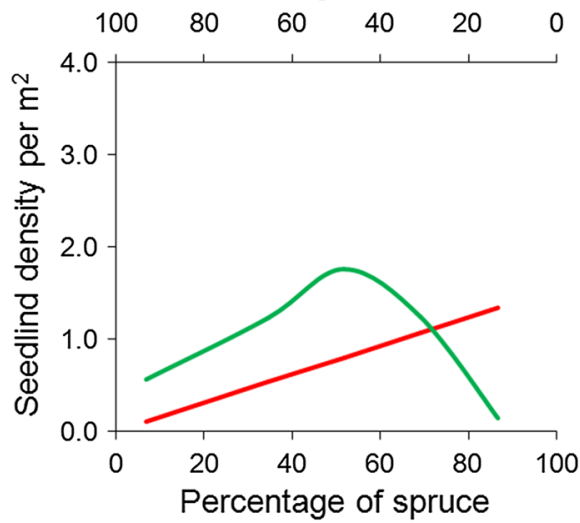

Percentage of fir

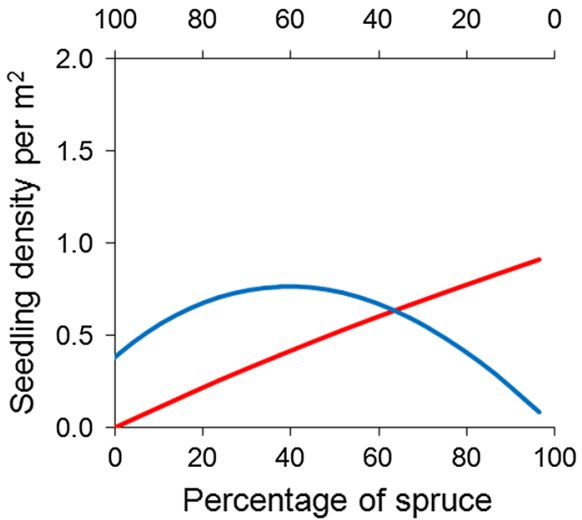

(Ujházy et al. 2017). In particular, heavy litter accumulations are often detrimental to conifer seedling survival because they are prone to drying and prevent seedling roots from quickly reaching the mineral soil (Greene et al. 1999; Asplund et al. 2017). A number of research studies have also indicated that spruce can effectively utilize micro-sites linked to coarse woody debris (Szewczyk and Szwagrzyk 1996; Orman and Szewczyk 2015). Unfortunately, however, the dataset used in this study does not provide information on seedlings established on deadwood and mineral soil. A positive effect of mature firs on spruce regeneration reported by Hofmeister et al. (2008), possibly attributable to a lower ectohumus layer depth and higher topsoil moisture around fir stems than around spruce stems (Paluch and Gruba 2012), could not be demonstrated by the results of the present study. 


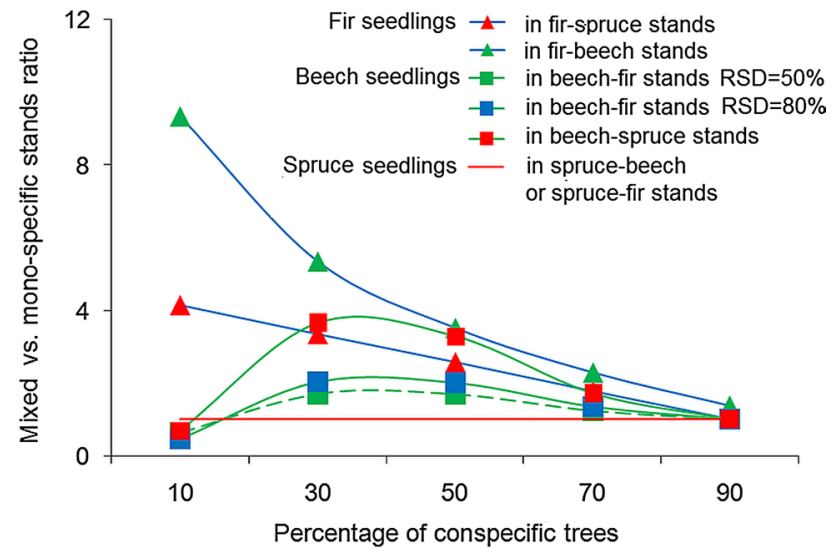

Fig. 8 Ratio of the relative seedling densities in the mixed-species stands of different species percentages and in the mono-species stands based on the relationships given in Table 3. Values $>1$ indicate that the relative seedling densities are higher in mixed-species than mono-specific stands (with a percentage of conspecific trees $>80 \%$ ). RSD relative stand density (in \%), see "Methods"

\section{Implications for natural stand dynamics and silviculture}

Both the empirical (Table 2) and modeled (Fig. 7) average seedling densities were higher than recommended for planting at artificial regeneration $\left(0.15-1.00\right.$ per $\mathrm{m}^{2}$ depending on species, Burschel and Huss 1997; Saniga 2010; Jaworski 2011) but relatively low compared to the maximum values in the dataset used in this analysis (Table 2) or reported in the literature (Schrempf 1978; Šimak 1951; Mayer 1960; Jaworski 1973; Jaworski et al. 1985, 2007; Ammer 1996b; Peltier et al. 1997; Szwagrzyk et al. 2001; Grassi et al. 2004; Hunziker and Brang 2005; Szwagrzyk et al. 2015; Paluch et al. 2016). Moreover, except for a negative correlation between the spruce seedlings and older regeneration (all species) in the beech-spruce mixtures, we did not find negative relationships either between seedling densities of different species or between seedling and sapling densities. This implies that in the stands under study neither intraspecific
Fig. 9 Expected species composition in the regeneration layer in stands of different species percentages in the overstorey. The values above/below the reference line (equal percentages in the overstorey and regeneration) denote excess/shortage of the species in the regeneration compared to the percentage in the basal area of the overstorey. Values were derived from the generalized linear models with parameters given in Table 3. $R S D$ relative stand density (in $\%$, see "Methods"

nor interspecific competition between juvenile individuals play a key role in shaping species composition or density level of regeneration cohorts. In addition, the weak but positive correlations between seedling densities in the beech-fir and beech-spruce mixtures suggest that the regenerative niches of these species partly overlap at this juvenile stage.

The analysis indicated a positive effect of admixed species in the overstorey on relative regeneration densities of fir regeneration (Fig. 8). These effects may be viewed as increase-when-rare mechanisms (Wilson 2011) that limit superior competitors and counteract the transformation of mixed stands into monocultures, because they result in a disproportionate percentage of the rare species in regeneration compared to the overstorey (Fig. 9). Under natural stand dynamics, an over-proportional percentage of spruce regeneration is likely to occur only in stands of a considerably reduced density and a low percentage of spruce. In the beech-spruce and beech-fir mixtures with balanced percentages of these species, a strong tendency for the proportion of beech to increase in the regeneration layer is to be expected. To a lesser degree, a similar trend may occur for fir regeneration in the fir-spruce mixtures. In sum, although the interactions documented here may influence species compositions of the future stands, their ultimate effect may depend heavily on other factors, such as the shading level at later developmental stages, its relation to species growth rate and competitive abilities, or species-specific resistance to herbivores.

The results indicate that a reduction in stand density promotes the establishment of spruce regeneration in the mixtures with fir and beech, but decreases the percentage of fir regeneration in the mixtures with beech. Thus, changing the density and proportions of the overstorey species with some advance (needed to modify forest floor and seedbed properties) is a powerful silvicultural tool to foster targeted tree species in the regeneration layer. In the context of conversion of spruce-dominated forests into mixed-species stands with fir and beech, a particularly urgent task in montane forests of Europe, the results indicate that only a relatively small percentage of fir in the overstorey is needed to effectively support this process through natural regeneration. But natural regeneration must be given the chance to succeed before such forests begin an irreversible decline.

Acknowledgements This work was supported by the National Science Centre, Poland [2012/07/B/NZ9/00953 to J.P.]. The authors wish to thank two referees for valuable and pertinent comments and the authorities of the Babiogórski, Bieszczadzki, Gorczański and Magurski NPs for making available the forest inventory data used in this study.

\section{Compliance with ethical standards}

Conflict of interest The authors declare that they have no conflict of interest.
Open Access This article is distributed under the terms of the Creative Commons Attribution 4.0 International License (http://creativeco mmons.org/licenses/by/4.0/), which permits unrestricted use, distribution, and reproduction in any medium, provided you give appropriate credit to the original author(s) and the source, provide a link to the Creative Commons license, and indicate if changes were made.

\section{References}

Amm A, Pichot Ch, Dreyfus P, Davi H, Fady B (2012) Improving the estimation of landscape scale seed dispersal by integrating seedling recruitment. Ann For Sci 69:845-856. https://doi. org/10.1007/s13595-012-0208-1

Ammer C (1996a) Impact of ungulates on structure and dynamics of natural regeneration of mixed mountain forests in the Bavarian Alps. For Ecol Manag 88:43-53. https://doi.org/10.1016/S0378 -1127(96)03808-X

Ammer C (1996b) Konkurrenz um Licht-zur Entwicklung der Naturverjungung im Bergmischwald. Schriftenreihe der Forstwissenschaftlichen Fakultät der Universität München und der Bayer. ForstlichenVersuchs- und Forschungsanstalt

Asplund J, Hustoft E, Nybakken L, Ohlson M, Lie M (2017) Litter impair spruce seedling emergence in beech forests: a litter manipulation experiment. Scand J For Res 33:332-337. https:// doi.org/10.1080/02827581.2017.1388440

Aussenac G (2000) Interactions between forest stands and microclimate: exophysiological aspects and consequences for silviculture. Ann For Sci 57:287-301. https://doi.org/10.1051/fores $\mathrm{t}: 2000119$

Barbier S, Gosselin F, Balandier P (2008) Influence of tree species on understory vegetation diversity and mechanisms involved-a critical review for temperate and boreal forests. For Ecol Manag 254:1-15. https://doi.org/10.1016/j.foreco.2007.09.038

Becker M, Drapier J (1985) Rôle de l'allélopathie dans les difficultés de régénération du sapin (Abies alba Mill.). Propriétés phytotoxiques des hydrosolubles d'aiguilles de sapin. Oecol Plant 5:347-356

Bens O, Buczko U, Sieber S, Hüttl RF (2006) Spatial variability of $\mathrm{O}$ layer thickness and humus forms under different pine beechforest transformation stages in NE Germany. J Plant Nutr Soil Sci 169:5-15. https://doi.org/10.1002/jpln.200521734

Brożek S, Zwydak M (2010) Atlas gleb leśnych Polski. Centrum Informacyjne Lasów Państwowych, Warszawa

Burschel P, Huss J (1997) Grundriss des Waldbaus. Verlag Paul Parey, Hamburg, p 488

Carson WP, Root RB (2000) Herbivory and plant species coexistence: community regulation by an outbreaking phytophagous insect. Ecol Monogr 70:73-99. https://doi.org/10.1890/00129 615(2000)070\%5b0073:hapscc\%5d2.0.co;2

Chernick MR, LaBudde RA (2011) An introduction to bootstrap methods with applications to R. Wiley, Hoboken

Chesson P (2000) Mechanisms of maintenance of species diversity. Ann Rev Ecol Syst 31:343-366. https://doi.org/10.1146/annur ev.ecolsys.31.1.343

Clark JS, Silman M, Kern R, Macklin E, HilleRisLambers J (1999) Seed dispersal near and far: patterns across temperate and tropical forests. Ecology 80:1475-1494. https://doi.org/10.1890/00129658(1999)080\%5b1475:sdnafp\%5d2.0.co;2

Cline E, Vinyard B, Edmonds R (2007) Spatial effects of retention trees on mycorrhizas and biomass of Douglas-fir seedlings. Can J For Res 37:430-438. https://doi.org/10.1139/X06-229

Comita LS, Queenborough SA, Murphy SJ, Eck JL, Xu K, Krishnadas M, Beckman N, Zhu Y, Gómez-Aparicio L (2014) Testing predictions of the Janzen-Connell hypothesis: a meta-analysis 
of experimental evidence for distance- and density-dependent seed and seedling survival. J Ecol 102:845-856. https://doi. org/10.1111/1365-2745.12232

Connell JH (1971) On the role of natural enemies in preventing competitive exclusion in some marine animals and in rain forest trees. In: den Boer PJ, Gradwell GR (eds) Dynamics of populations. Centre for Agricultural Publishing and Documentation, Wageningen, pp 298-312

De Andrés EG, Camarero JJ, Martínez I, Coll L (2014) Uncoupled spatiotemporal patterns of seed dispersal and regeneration in Pyrenean silver fir populations. For Ecol Manag 319:18-28. https:// doi.org/10.1016/j.foreco.2014.01.050

Devaney JL, Whelan PM, Jansen MAK (2018) Conspecific negative density dependence in a long-lived conifer, yew Taxus baccata $\mathrm{L}$. Eur J For Res 137:69-78. https://doi.org/10.1007/s10342-01710 91-y

Dobrowolska D (1998) Structure of silver fir (Abies alba Mill.) natural regeneration in the "Jata" reserve in Poland. For Ecol Manag 110:237-247. https://doi.org/10.1016/S03781127(98)00286-2

Dobrowolska D, Veblen TT (2008) Treefall-gap structure and regeneration in mixed Abies alba stands in central Poland. For Ecol Manag 255:3469-3476. https://doi.org/10.1016/j.foreco.2008.02.025

Duchesneau R, Morin H (1999) Early seedling demography in balsam fir seedling bank. Can J For Res 29:1502-1509. https://doi. org/10.1139/x99-090

Forbes C, Evans M, Hastings N, Peacock B (2011) Statistical distributions. Wiley, Hoboken

Forrester DI, Albrecht AT (2014) Light absorption and light-use efficiency in mixtures of Abies alba and Picea abies along a productivity gradient. For Ecol Manag 328:94-102. https://doi. org/10.1016/j.foreco.2014.05.026

Forrester DI, Bauhus J (2016) A review of processes behind diversityproductivity relationships in forests. Curr For Reports 2:45-61. https://doi.org/10.1007/s40725-016-0031-2

Fotis AT, Morin TH, Fahey RT, Hardiman BS, Bohrer G, Curtis PS (2018) Forest structure in space and time: biotic and abiotic determinants of canopy complexity and their effects on net primary productivity. Agr For Met 250-251:181-191. https://doi. org/10.1016/j.agrformet.2017.12.251

Frankland JC (1998) Fungal succession-unravelling the unpredictable. Mycol Res 102:1-15. https://doi.org/10.1017/S095375629 7005364

Gómez JM (2004) Importance of microhabitat and acorn burial on Quercus ilex early recruitment: non-additive effects on multiple demographic processes. Plant Ecol 172:287-297. https://doi. org/10.1023/B:VEGE.0000026327.60991.f9

Grassi G, Minotta G, Tonon G, Bagnaresi U (2004) Dynamics of Norway spruce and silver fir natural regeneration in a mixed stand under uneven-aged management. Can J For Res 34:141-149. https ://doi.org/10.1139/x03-197

Grebenc T, Christensen M, Vilhar U, Čater M, Martín MP, Simončič P, Kraigher H (2009) Response of ectomycorrhizal community structure to gap opening in natural and managed temperate beech-dominated forests. Can J For Res 39:1375-1386. https:// doi.org/10.1139/X09-072

Greene DF, Zasada JC, Sirois L, Kneeshaw D, Morin H, Charron I, Simard MJ (1999) A review of the regeneration dynamics of North American boreal forest tree species. Can J For Res 29:824839. https://doi.org/10.1139/x98-112

Hartley SE, Iason GR, Duncan AJ, Hitchcock D (1997) Feeding behaviour of red deer (Cervus elaphus) offered Sitka Spruce saplings (Picea sitchensis) grown under different light and nutrient regimes. Funct Ecol 11:348-357. https://doi.org/10.1046/j.13652 435.1997.00094.x
Hirsch B, Kays R, Pereira VE, Jansen PA, Rejmanek M (2012) Directed seed dispersal towards areas with low conspecific tree density by a scatter-hoarding rodent. Ecol Lett 15:1423-1429. https://doi. org/10.1111/ele. 12000

Hofmeister Š, Svoboda M, Souček J, Vacek S (2008) Spatial pattern of Norway spruce and silver fir natural regeneration in unevenaged mixed forests of northeastern Bohemia. J For Sci 54:92-101

Hunziker U, Brang P (2005) Microsite patterns of conifer seedling establishment and growth in a mixed stand in the southern Alps. For Ecol Manag 210:67-79. https://doi.org/10.1016/j.forec o.2005.02.019

Huth F, Wehnert A, Tiebel K, Wagner S (2017) Direct seeding of silver fir (Abies alba Mill.) to convert Norway spruce (Picea abies L.) forests in Europe: a review. For Ecol Manag 403:61-78. https:// doi.org/10.1016/j.foreco.2017.08.017

Janík D, Král K, Adam D, Hort L, Samonil P, Unar P, Vrška T, McMahon S (2016) Tree spatial patterns of Fagus sylvatica expansion over 37 years. For Ecol Manag 375:134-145. https://doi. org/10.1016/j.foreco.2016.05.017

Jankowiak R, Bilański P, Paluch J, Kołodziej Z (2016) Fungi associated with dieback of Abies alba seedlings in naturally regenerating forest ecosystems. Fungal Ecol 24:61-69. https://doi.org/10.1016/j. funeco.2016.08.013

Janzen DH (1970) Herbivores and the number of tree species in tropical forests. Am Natur 104:501-528. https://doi.org/10.1086/282687

Jaworski A (1973) Odnowienie naturalne jodły (Abies alba Mill.) w wybranych zbiorowiskach leśnych Parków Narodowych: Tatrzańskiego, Babiogórskiego i Pienińskiego. Acta Agr et Silv ser Silv 13:21-87

Jaworski A (2011) Hodowla lasu. Sposoby zagospodarowania, odnawianie lasu, przebudowa i przemiana drzewostanów. PWRiL, Poznań, p 556

Jaworski A, Czuba K, Jamrozik T (1985) Ocena naturalnych odnowień jodły i świerka w wybranych drzewostanach w Leśnym Zakładzie Doświadczalnym w Krynicy. Zesz Nauk AR w Krakowie 197:25-37

Jaworski A, Paluch J, Pach M, Kołodziej Z, Majerczyk K (2007) Charakterystyka lasów przerębowych w wybranych nadleśnictwach Regionalnej Dyrekcji Lasów Państwowych. Sylwan 151:34-52

Jonášová M, Prach K (2004) Central-European mountain spruce (Piceaabies (L.) Karst.) forests: regeneration of tree species after a bark beetle outbreak. Ecol Eng 23:15-27. https://doi. org/10.1016/j.ecoleng.2004.06.010

Juchheim J, Annighöfer P, Ammer C, Calders K, Raumonen P, Seidel D (2017) How management intensity and neighborhood composition affect the structure of beech (Fagus sylvatica L.) trees. Trees 31:1723-1735. https://doi.org/10.1007/s00468-017-1581-z

Kelly D, Sork VL (2002) Mast seeding in perennial plants: why, how, where? Ann Rev Ecol Syst 33:427-447. https://doi.org/10.1146/ annurev.ecolsys.33.020602.095433

Kohlermann L (1950) Untersuchungen über die Windverbreitung der Früchte und Samen mitteleuropäischer Waldbäume. Forstwiss Cbl 69:606-624

Korpel' Š, Vinš B (1965) Pestovanie jedle. SVPHL, Bratislava

Král K, Valtera M, Janík D, Šamonil P, Vrška T (2014) Spatial variability of general stand characteristics in central European beechdominated natural stands-effects of scale. For Ecol Manag 328:353-364. https://doi.org/10.1016/j.foreco.2014.05.046

Kucbel S, Saniga M, Jaloviar P, Vencurik J (2012) Stand structure and temporal variability in old growth beech-dominated forests of the northwestern Carpathians: a 40-years perspective. For Ecol Manag 264:125-133. https://doi.org/10.1016/j.foreco.2011.10.011

Leuschner Ch (2002) Forest succession and water resources: soil hydrology and ecosystem water turnover in early, mid and late 
stages of a 300-yr-long chronosequence on sandy soil. In: Dohrenbush A, Bartsch N (eds) Forest development. Succession, environmental stress and forest management. Case studies. Springer, Berlin, pp 1-68

Levia DF, Frost EE (2003) A review and evaluation of stemflow literature in the hydrologic and biogeochemical cycles of forested and agricultural ecosystems. J Hydrol 274:1-29. https://doi. org/10.1016/S0022-1694(02)00399-2

Madsen P (1995) Effects of seedbed type on wintering of beech nuts (Fagus sylvatica) and deer impact on sprouting seedlings in natural regeneration. For Ecol Manag 73:37-43. https://doi. org/10.1016/0378-1127(94)03503-O

Matuszkiewicz JM (2001) Zespoły leśne Polski. Wydawnictwo Naukowe PWN, Warszawa

Mayer H (1960) Bodenvegetation und Naturverjüngung von Tanne und Fichte in einem Allgäuer Plenterwald. Ber Geobot Inst ETH Stiftung Rübel Zürich 3:19-42

Millerón M, López de Heredia U, Lorenzo Z, Alonso J, Dounavi A, Gil L, Nanos N (2013) Assessment of spatial discordance of primary and effective seed dispersal of European beech (Fagus sylvatica L.) by ecological and genetic methods. Mol Ecol 22:1531-1545. https://doi.org/10.1111/mec.12200

Nagel TA, Svoboda M, Rugani T, Diaci J (2010) Gap regeneration and replacement patterns in an old-growth Fagus-Abies forest of Bosnia-Herzegovina. Plant Ecol 208:307-318. https://doi. org/10.1007/s11258-009-9707-z

Ohse B, Seele C, Holzwarth F, Wirth C (2017) Different facets of tree sapling diversity influence browsing intensity by deer dependent on spatial scale. Ecol Evol 7:6779-6789. https://doi. org/10.1002/ece3.3217

Orman O, Szewczyk J (2015) European beech, silver fir, and Norway spruce differ in establishment, height growth, and mortality rates on coarse woody debris and forest floor-a study from a mixed beech forest in the Western Carpathians. Ann For Sci 72:955-965. https://doi.org/10.1007/s13595-015-0492-7

Övergaard R, Gemmel P, Karlsson M (2007) Effects of weather conditions on mast year frequency in beech (Fagus sylvatica L.) in Sweden. Forestry 80:555-565. https://doi.org/10.1093/fores try/cpm020

Packer A, Clay K (2003) Soil pathogens and Prunus serotina seedling and sapling growth near conspecific trees. Ecology 84:108 119. https://doi.org/10.1890/00129658(2003)084\%5b010 8:spapss\%5d2.0.co;2

Paluch J (2011) Ground seed density patterns under conditions of strongly overlapping seed shadows in Abies alba Mill. stands. Eur J For Res 130:1009-1022. https://doi.org/10.1007/s1034 2-011-0486-4

Paluch J, Gruba P (2012) Effect of local species composition on topsoil properties in mixed stands with silver fir (Abies alba Mill.). Forestry 85:413-426. https://doi.org/10.1093/forestry/cps040

Paluch J, Jastrzębski R (2013) Natural regeneration of shade-tolerant Abies alba Mill. in gradients of stand species compositions: limitation by seed availability or safe microsites? For Ecol Manag 307:322-332. https://doi.org/10.1016/j.foreco.2013.06.035

Paluch J, Stępniewska H (2012) Effect of microsites on the survival, density, and ectomycorrhizal status of shade-tolerant Abies alba regeneration attacked by fungal pathogens. Can J For Res 42:720-732. https://doi.org/10.1139/x2012-015

Paluch J, Kołodziej Z, Pach M, Jastrzębski R (2015) Spatial variability of close-to-primeval Fagus-Abies-Picea forests in the Western Carpathians (Central Europe): a step towards a generalised pattern. Eur J For Res 134:235-246. https://doi.org/10.1007/ s10342-014-0846-y

Paluch J, Kołodziej Z, Skrzyszewski J, Bartkowicz L, Gruba P (2016) Regeneration patterns of the late-successional Abies alba Mill.: inhibition in monospecific stands and colonization in mixed stands. Ann For Sci 73:1015-1024. https://doi.org/10.1007/ s13595-016-05732

Paszyński J, Niedzwiedź T (1999) Klimat. In: Starkel L (ed) Geografia Polski. Środowisko przyrodnicze. PWN, Warszawa, pp 288-343

Peltier A, Touzet MC, Armengaud C, Ponge JF (1997) Establishment of Fagus sylvatica and Fraxinus excelsior in an old-growth beech forest. J Veg Sci 8:13-20. https://doi.org/10.2307/32372 37

Pérez-Ramos IM, Marañón T (2008) Factors affecting post-dispersal seed predation in two coexisting oak species: microhabitat, burial and exclusion of large herbivores. For Ecol Manag 255:35063514. https://doi.org/10.1016/j.foreco.2008.02.032

Polyakova O, Billor N (2007) Impact of deciduous tree species on litterfall quality, decomposition rates and nutrient circulation in pine stands. For Ecol Manag 253:11-18. https://doi.org/10.1016/j. foreco.2007.06.049

Pretzsch H (2014) Canopy space filling and tree crown morphology in mixed-species stands compared with monocultures. For Ecol Manag 327:251-264. https://doi.org/10.1016/j.foreco.2014.04.027

Robakowski P, Wyka T, Samardakiewicz S, Kierzkowski D (2004) Growth, photosynthesis, and needle structure of silver fir (Abies alba Mill.) seedlings under different canopies. For Ecol Manag 201:211-227. https://doi.org/10.1016/j.foreco.2004.06.029

Ruscoe WA, Elkinton JS, Choquenot D, Allen RB (2005) Predation of beech seed by mice: effects of numerical and functional responses. J Anim Ecol 74:1005-1019. https://doi.org/10.111 1/j.1365-2656.2005.00998.x

Sagnard F, Pichot C, Dreyfus P, Jordano P, Fady B (2007) Modelling seed dispersal to predict seedling recruitment: recolonization dynamics in a plantation forest. Ecol Model 203:464-474. https:// doi.org/10.1016/j.ecolmodel.2006.12.008

Saniga M (2010) Pestovanie lesa. Technická Univerzita vo Zvolene, Lesnická fakulta, $221 \mathrm{pp}$

Schnur JL, Canham CD, Ostfeld RS, Inouye RS (2004) Neighborhood analyses of small mammal dynamics: impacts on seed predation and seedling establishment. Ecology 85:741-755. https://doi. org/10.1890/02-0644

Schrempf W (1978) Analyse der Verjüngung im Fichten-TannenBuchen-Urwald Rothwald in Niederösterreich. Centralblatt für das gesamte Forstwesen 95:217-245

Schume H, Jost G, Katzensteiner K (2003) Spatio-temporal analysis of the soil water content in a mixed Norway spruce (Picea abies (L.) Karst.)-European beech (Fagus sylvatica L.) stand. Geoderma 112:273-287. https://doi.org/10.1016/S0016-7061(02)00311-7

Šimak M (1951) Untersuchungen über den natürlichen Baumartenwechsel in schweizerischen Plenterwäldern. Mitteilungen der Schweizerischen Anstalt für das Forstliche Versuchswesen 27:406468. https://doi.org/10.3929/ethz-a-000294365

Simard MJ, Bergeron Y, Sirois L (2003) Substrate and litterfall effects on conifer seedling survivorship in southern boreal stands of Canada. Can J For Res 33:672-681. https://doi.org/10.1139/x02-204

Stancioiu PT, O'Hara KL (2006) Regeneration growth in different light environments of mixed-species, multiaged, mountainous forests of Romania. Eur J For Res 125:151-162. https://doi.org/10.1007/ s10342-005-0069-3

Stanisz A (2007) Przystępny kurs statystyki z zastosowaniem STATISTICA PL na przykładach z medycyny. Tom II. Modele liniowe i nieliniowe. StatSoft Polska, Kraków

Szewczyk J, Szwagrzyk J (1996) Tree regeneration on rotten wood and on soil in old-growth stand. Vegetatio 122:37-46. https://doi. org/10.1007/BF00052814

Szwagrzyk J, Szewczyk J, Bodziarczyk J (2001) Dynamics of seedling banks in beech forest: results of a 10-year study on germination, growth and survival. For Ecol Manag 141:237-250. https://doi. org/10.1016/S0378-1127(00)00332-7 
Szwagrzyk J, Gratzer G, Stępniewska H, Szewczyk J, Veselinovic B (2015) High reproductive effort and low recruitment rates of European beech: is there a limit for the superior competitor? Pol J Ecol 63:198-212. https://doi.org/10.3161/15052249PJE2015.63.2.004

Tan BS, Bruckert S (1992) Effet des facteurs physiques de l'environnement sur les premiers stades de la regeneration naturelle du sapin pectine (Abies alba Mill.) dans certaines stations du Jura. Ann For Sci 49:337-349. https://doi.org/10.1051/ forest: 19920403

Ujházy K, Hederová L, Máliš F, Ujházyová M, Bosela M, Čiliak M (2017) Overstorey dynamics controls plant diversity in ageclass temperate forests. For Ecol Manag 391:96-105. https://doi. org/10.1016/j.foreco.2017.02.010

Wagner S, Collet C, Madsen P, Nakashizuka T, Nyland RD, SaghebTalebi K (2010) Beech regeneration research: from ecological to silvicultural aspects. For Ecol Manag 259:2172-2182. https://doi. org/10.1016/j.foreco.2010.02.029

Wilson JB (2011) The twelve theories of co-existence in plant communities: the doubtful, the important and the unexplored. J Veg Sci 22:184-195. https://doi.org/10.1111/j.16541103.2010.01226.x

Yamazaki M, Iwamoto S, Seiwa K (2009) Distance- and densitydependent seedling mortality caused by several diseases in eight tree species co-occurring in a temperate forest. Plant Ecol 201:181-196. https://doi.org/10.1007/978-90-481-2795-5_14

Publisher's Note Springer Nature remains neutral with regard to jurisdictional claims in published maps and institutional affiliations. 